\title{
A study on Effect of Nutrition Supplementation in Children Living With HIV at ART Centre- A Prospective Observational Study
}

\author{
Muddana Narasimha Rao', Ashish Ragireddy ${ }^{2}$ \\ ${ }^{1}$ Assistant Professor, Department of Paediatrics, Shadan Institute of Medical Sciences, Hyderabad, Telangana, India, ${ }^{2}$ MD, Paediatrics, Shadan Institute of Medical \\ Sciences, Hyderabad, Telangana, India.
}

\section{Abstract}

Background: The nutritional status of people living with HIV/AIDS is related to morbidity and mortality and may predict the course of HIV infection and the management of these helps in recovery and maintenance of health status. Aims \& objectives: The main aim of the current study to assess the nutritional status and nutritional supplementation in children with HIV at ART center. Subjects and Methods: A prospective observational study was conducted between May 2017 and May 2018 in a total of 100 children aged 1 to 18 years with proven HIV status attending ART centre. Each child included in the study was examined clinically and their anthropometric data was recorded. They were provided with a fixed nutrition supplementation of 2 scoops of protein powder and one serving of peanut chikki per day and they were followed up regularly. At the end of one year, they were examined clinically and their anthropometric data was recorded again. Result: In the present study, about $44 \%$ of subjects were males and 56\% were females. Majority of the children (55\%) fell in the age group of 11-15 years. $36 \%$ were on pre-ART and $64 \%$ were on ART. At the beginning of the study, $59 \%$ of children were stunted and $64 \%$ of the children had < 2 $\mathrm{SD}$ of BMI for age. According to WHO, Z scores could be calculated only for children less than 10 years of age. In this study, 34 children fell in this age group and 24 among them were underweight at the beginning of the study. Conclusion: After giving the nutritional supplementation for a period of one year, there was a statistically significant improvement in height-for-age, weight-for-age and the $\mathrm{Z}$ scores of height-for-age, weight-for-age and BMI-for-age. Though there was an improvement in the mean values of BMI for age, this was not considered to be statistically significant. Finally, nutritional interventions should be tailored and assessed to improve growth, especially at time of ART initiation that could lead to an optimisation of their clinical response and survival of ART-treated children.

Keywords: Children, HIV, Nutritional Supplements, Z-score, ART centre, BMI.

Corresponding Author: Dr. Ashish Ragireddy, MD, Paediatrics, Shadan Institute of Medical Sciences, Hyderabad, Telangana, India. Email: jaffarshaik4407@gmail.com

Received: January 2020

Accepted: January 2020

\section{Introduction}

Since the first cases of human immunodeficiency virus (HIV) infection were identified, the number of children infected with HIV has risen dramatically in developing countries, the result of an increased number of HIV-infected women of childbearing age in these areas. HIV is a retrovirus and can be transmitted vertically, sexually, or via contaminated blood products or IV drug abuse. ${ }^{[1]}$ Vertical HIV infection occurs before birth, during delivery, or after birth. ${ }^{[2]}$ HIV children suffer from malnutrition and a lot of opportunistic infections. Malnutrition and growth failure are among the most frequent clinical consequences of HIV/AIDS in children. ${ }^{[3]}$ Children experience more rapid disease progression than adults, with up to half of untreated children dying within the first 2 years of life.

India is now estimated to have 2.4 million people, largest in Asia and 3 rd in the world of which $3.5 \%$ are children. ${ }^{[4,5]}$ HIV/AIDS is responsible for $2 \%$ of under five deaths in the world. Under-nutrition childhood is estimated to cause 3.1 million child deaths annually through a common potentiating effect on common infections like pneumonia and diarrhea. ${ }^{[6]}$ Assessment of nutritional status by anthropometric measurements like weight, height has been widely used in epidemiological studies as it is easy to estimate, affordable and easy to carry out. ${ }^{[7]}$ Malnutrition is common in HIV infected children due to a complex interplay of recurrent infections, decreased intake due to illness, lesions like candidiasis and decreased availability due to social problems like ill or deceased caretaker and increased metabolic rate. ${ }^{[8]}$ The nutritional status of people living with HIV/AIDS is related to morbidity and mortality and may predict the course of HIV infection and the management of these helps in recovery and maintenance of health status. ${ }^{[7]}$ Malnutrition is both a manifestation as well as an independent risk factor for death in HIV. ${ }^{9]}$

Multiple strategies to improve nutritional outcomes exist, including antiretroviral therapy (ART), treatment of coinfections, nutritional counseling, and medications affecting 
intake or metabolism and exogenous delivery of nutrients with nutritional supplements. ${ }^{[10]}$ Most research to date has occurred in developed countries, but the application of knowledge is currently needed, and will be increasingly needed, in developing settings, where the burden of HIV disease is highest. ${ }^{[10]}$

Hence; the present study to assess the nutritional status and nutritional supplementation in children with HIV.

\section{Subjects and Methods}

A prospective observational study was conducted between May 2017 - May 2018. The study proposal was approved by the ethical committee of Shadan Institute of Medical Sciences, Peerancheru.

A total of 100 children with proven HIV status attending ART centre were included in the study.

\section{Inclusion criteria}

- Children aged 1-18 years with proven HIV positive status.

\section{Exclusion criteria}

- Those who did not give consent.

- Those with advanced stage HIV.

Before data collection, permission and co-operation were sought from the care takers of all the children. The nature and the purpose of the study with associated risks and benefits were also described in detail individually, confidentiality of their information was assured, and after that written consent was obtained from all of them.

\section{Data collection}

Each child included in the study was examined clinically and their anthropometric data (baseline) was recorded. They were provided with a fixed nutrition supplementation everyday along with their daily intake for a period of one year.

\section{Details of nutrition supplementation given:}

$>2$ scoops of Protein powder / day

- Total amount: $60 \mathrm{gms}$

- Total calorie: $210 \mathrm{kcal}$

- Total protein: $19.2 \mathrm{gms}$

Peanut chikki - one serving

- Total amount :30gms

- Total calorie: $150 \mathrm{kcal}$

- Total protein: $4 \mathrm{gms}$

\section{Total calories: $360 \mathrm{kcal}$}

* Total proteins: $23.2 \mathrm{gms}$

They were followed up regularly. At the end of one year, they were examined clinically and their anthropometric data was recorded.

The anthropometric parameters taken into consideration in this study are height for age (HFA), weight for age (WFA) and BMI for age.

The $\mathrm{Z}$ scores for weight, height and BMI were computed based on child's age and gender using standard references wherever possible [using WHO Anthro software (version 3.2.2.) and WHO Anthro Plus software]. ${ }^{[1,12]}$

To define malnutrition, WHO definitions were adopted: ${ }^{[13]}$

- Height for age - for children up to 18 years

- Weight for age - for children less than 10 years.

- $\quad$ BMI for age - for children up to 18 years

The WHO recommends a $\mathrm{Z}$ score cutoff point of $<-2 \mathrm{SD}$ to classify low height for age (stunting) and low weight for age and BMI for age (underweight).

\section{Data analysis and presentation}

All the collected data were compiled and entered into Microsoft Excel 2016. Data was checked for consistency and completeness, and then analysed using SPSS version 25.0 software. Descriptive statistics were followed, and mean, SD, etc. were calculated. Paired t test was used to determine whether there are any significant differences between the anthropometric parameters at the baseline (beginning of study) and at the end of one year.

\section{Results}

Table 1: Sex distribution

\begin{tabular}{|l|l|l|}
\hline Gender & No. Of Children & Percentage \\
\hline Male & 44 & $44 \%$ \\
\hline Female & 56 & $56 \%$ \\
\hline Total & 100 & $100 \%$ \\
\hline
\end{tabular}

Out of the 100 children included in this study, $44 \%$ were males and $56 \%$ were females.

Table 2: Age Distribution
\begin{tabular}{|l|l|l|l|}
\hline $\begin{array}{l}\text { Age Group } \\
\text { (In } \\
\text { Years) }\end{array}$ & Males & Females & $\begin{array}{l}\text { Total No. Of } \\
\text { Children }\end{array}$ \\
\hline 0 to 5 & $1(33.33 \%)$ & $2(66.67 \%)$ & 3 \\
\hline 6 to 10 & $16(43.24 \%)$ & $21(56.76 \%)$ & 37 \\
\hline 11 to 15 & $25(45.45 \%)$ & $30(54.55 \%)$ & 55 \\
\hline$>15$ & $2(40 \%)$ & $3(60 \%)$ & 5 \\
\hline Total & $44(44 \%)$ & $56(56 \%)$ & 100 \\
\hline
\end{tabular}

Majority of the children fell in the age group between 11-15 years, of which $45.45 \%$ were males and $54.55 \%$ were females.

Children less than 5 years were only 3 in number; least age being 4 years. The highest age taken was 18 years. Mean age being $11.02 \pm 3.16$ years. The mean age of males was $11.16 \pm 3.15$ years and that of females was $10.91 \pm 3.20$ 
years.

\section{$\underline{\text { ART Status }}$}

Table 3: Art Status

\begin{tabular}{|l|l|l|}
\hline Art Status & No. Of Children & Total \\
\hline PRE-ART till the end of the study & 36 & $36 \%$ \\
\hline ON ART since the beginning of study & 64 & $64 \%$ \\
\hline TOTAL & 100 & $100 \%$ \\
\hline
\end{tabular}

$36 \%$ of the children belonged to pre-ART, $64 \%$ of the children were already on ART at the beginning of the study.

\section{Assessment of nutritional status at the beginning of study}

\section{- Height for age}

\begin{tabular}{|l|l|l|l|}
\hline Table 4: Assessment of height for age at the beginning of study \\
\hline $\begin{array}{l}\text { Assessment of } \\
\text { height }\end{array}$ & Males (\%) & $\begin{array}{l}\text { Females } \\
(\%)\end{array}$ & $\begin{array}{l}\text { Total no. of } \\
\text { children }\end{array}$ \\
\hline Normal & $22(50 \%)$ & $19(34 \%)$ & 41 \\
\hline Stunted & $22(50 \%)$ & $37(66 \%)$ & 59 \\
\hline Total & 44 & 56 & 100 \\
\hline
\end{tabular}

The mean height was $134.21 \pm 18.03 \mathrm{~cm} .59 \%$ of the total study sample were stunted i.e. their height was more than two standard deviations ( $<2 \mathrm{SD})$ below their median height for age and gender. Among those children with stunting, 22 were boys and 37 were girls. Out of the $41 \%$ children with normal height for age (i.e. those who fall within the 2 SD of their median), 22 were boys and 19 were girls. The mean height for boys was $138.02 \pm 18.52 \mathrm{~cm}$ and the mean height for girls was $131.22 \pm 17.22 \mathrm{~cm}$. The mean height for age $\mathrm{Z}$ scores (HAZ) at the beginning of the study was $-1.55 \pm 1.66$.

\section{Weight for age}

\begin{tabular}{|l|l|l|l|}
\hline Table 5: Assessment of weight-for-age at the beginning of study \\
\hline $\begin{array}{l}\text { Assessment of } \\
\text { weight }\end{array}$ & Males (\%) & Females $(\%)$ & $\begin{array}{l}\text { Total no. of } \\
\text { children } \\
(\mathbf{n}=\mathbf{3 4})\end{array}$ \\
\hline Normal & $5(36 \%)$ & $5(25 \%)$ & 10 \\
\hline Underweight & $9(64 \%)$ & $15(75 \%)$ & 24 \\
\hline Total & 14 & 20 & 34 \\
\hline
\end{tabular}

The mean weight for age was $27.98 \pm 10.49 \mathrm{~kg}$. In boys, the mean was $29.42 \pm 10.3 \mathrm{~kg}$ and in girls it was $26.86 \pm 10.59$ $\mathrm{kg}$. Among the 100 children, 34 fell in the $<10$ year age group and hence $\mathrm{z}$ scores could be calculated only in them. The mean WAZ score for $<10$ years was $-2.45 \pm 0.99$. Among these 34 children in whom the $\mathrm{z}$ score could be calculated, 24 children were underweight i.e. their weight for age was more than 2 SD below the median weight for age. Therefore, among the 34 children in whom the weight for age score could be calculated, $70 \%$ were underweight.

\section{BMI for age}

Table 6: Assessment of BMI-for-age at the beginning of study

\begin{tabular}{|l|l|l|l|}
\hline $\begin{array}{l}\text { Assessment of } \\
\text { BMI }\end{array}$ & Males (\%) & Females (\%) & Total \\
\hline Normal & $13(29.5 \%)$ & $23(41 \%)$ & 36 \\
\hline Underweight & $31(70.5 \%)$ & $3359 \%)$ & 64 \\
\hline Total & 44 & 56 & 100 \\
\hline
\end{tabular}

The mean BMI in the present study is $14.87+2.04 \mathrm{~kg} / \mathrm{m} 2$. The mean BMI in boys is $14.86 \pm 1.71 \mathrm{~kg} / \mathrm{m} 2$ and in girls it is $14.87 \pm 2.28 \mathrm{~kg} / \mathrm{m} 2$. 64 children were underweight of which 31 were boys and 33 were girls. The mean BMI for age $\mathrm{z}(\mathrm{BAZ})$ score was $-1.69 \pm 0.83$.

\section{Anthropometric parameters at the beginning of study}

\begin{tabular}{|c|c|c|c|}
\hline Parameters & Males & Females & Overall \\
\hline $\begin{array}{l}\text { Height for age } \\
(\mathrm{cm})\end{array}$ & $138.02 \pm 18.52$ & $131.22 \pm 17.22$ & $\begin{array}{l}134.21 \pm \\
18.03\end{array}$ \\
\hline $\begin{array}{l}\text { Weight for age } \\
\text { (kg) }\end{array}$ & $29.42 \pm 10.3$ & $26.86 \pm 10.59$ & $27.98 \pm 10.49$ \\
\hline $\begin{array}{l}\text { BMI for age } \\
\left(\mathrm{kg} / \mathrm{m}^{2}\right)\end{array}$ & $14.86 \pm 1.71$ & $14.87 \pm 2.28$ & $14.87 \pm 2.04$ \\
\hline
\end{tabular}

\section{Assessment of nutritional status at the end of one year.}

\section{- Height for age}

Table 8: Assessment of height for age at the end of one year

\begin{tabular}{|l|l|l|l|}
\hline $\begin{array}{l}\text { Assessment of } \\
\text { height }\end{array}$ & Males (\%) & $\begin{array}{l}\text { Females } \\
(\mathbf{\%})\end{array}$ & $\begin{array}{l}\text { Total no. of } \\
\text { children }\end{array}$ \\
\hline Normal & $24(54.5 \%)$ & $22(39.3 \%)$ & 46 \\
\hline Stunted & $20(45.5 \%)$ & $34(60.7 \%)$ & 54 \\
\hline Total & 44 & 56 & 100 \\
\hline
\end{tabular}

The mean height was $139.06 \pm 17.65 \mathrm{~cm}$. At the end of one year, with the given nutrition supplementation $54 \%$ of the total study sample were stunted. 20 were boys and 34 were girls. Out of the $46 \%$ children with normal height for age, 24 were boys and 22 were girls.

The mean height for boys was $143.02 \pm 18.19 \mathrm{~cm}$ and the mean height for girls was $135.95 \pm 16.73 \mathrm{~cm}$. The improvement in height for age with the given nutritional supplementation is considered to be statistically significant $(\mathrm{p}<0.05)$.

In this study the mean height for age $\mathrm{Z}$ scores (HAZ) at the end of one year was $-1.45 \pm$ There is a statistically significant increase in HAZ score from baseline to 1 year ( $Z$ score change, $\mathrm{p}$ value $<0.05$ ).

\section{Weight for Age}

The mean weight for age was $30.93 \pm 10.09 \mathrm{~kg}$. In boys, the mean was $33.55 \pm 9.7 \mathrm{~kg}$ and in girls it was $28.87 \pm 9.98 \mathrm{~kg}$. The improvement in weight for age with the nutrition supplementation is considered to be statistically significant $(\mathrm{p}<0.05)$.

\section{BMI for Age}

Table 9: Assessment of BMI-for-age at the end of one year:

\begin{tabular}{|l|l|l|l|}
\hline $\begin{array}{l}\text { Assessment of } \\
\text { BMI }\end{array}$ & Males (\%) & Females (\%) & Total \\
\hline Normal & $33(75 \%)$ & $37(66 \%)$ & 70 \\
\hline Underweight & $11(25 \%)$ & $19(34 \%)$ & 30 \\
\hline Total & 44 & 56 & 100 \\
\hline
\end{tabular}

The mean BMI at the end of one year was $14.97 \pm 2.02$ $\mathrm{kg} / \mathrm{m} 2$. The mean BMI in boys was $15.57 \pm 1.65 \mathrm{~kg} / \mathrm{m} 2$ and 
that in girls was $14.55 \pm 2.13 \mathrm{~kg} / \mathrm{m} 2$. The improvement in $\mathrm{BMI}$ at the end of one year was not statistically significant $(\mathrm{p}=0.42)$. The BAZ score at the end of one year was $-1.41 \pm$ 1.22 . There is a statistically significant increase in BAZ score from baseline to 1 year $(0.84 \mathrm{Z}$ score change, $\mathrm{p}$ value $<0.05)$.

\section{Anthropometric Parameters at the End of One Years}

\begin{tabular}{|l|l|l|l|}
\hline Table 10: Anthropometric parameters at the end of one year \\
\hline PARAMETERS & Males & Females & Overall \\
\hline $\begin{array}{l}\text { Height for age } \\
(\mathrm{cm})\end{array}$ & $143.02 \pm 18.19$ & $135.95 \pm 16.73$ & $\begin{array}{l}139.06 \pm \\
17.65\end{array}$ \\
\hline $\begin{array}{l}\text { Weight for age } \\
(\mathrm{kg})\end{array}$ & $33.55 \pm 9.7$ & $28.87 \pm 9.98$ & $30.93 \pm 10.09$ \\
\hline $\begin{array}{l}\text { BMI for age } \\
\left(\mathrm{kg} / \mathrm{m}^{2}\right)\end{array}$ & $15.57 \pm 1.65$ & $14.55 \pm 2.13$ & $14.97 \pm 2.02$ \\
\hline
\end{tabular}

Table 10: Comparison of anthropometric parameters between baseline and end of one year

\begin{tabular}{|l|l|l|l|l|l|}
\hline Parameter & $\begin{array}{l}\text { At the } \\
\text { beginning } \\
\text { of the } \\
\text { study }\end{array}$ & $\begin{array}{l}\text { At the } \\
\text { end of } \\
\text { one } \\
\text { year }\end{array}$ & $\begin{array}{l}\mathbf{t} \\
\text { value }\end{array}$ & $\begin{array}{l}\mathbf{p} \\
\text { value }\end{array}$ & $\begin{array}{l}\text { Stastistical } \\
\text { significance }\end{array}$ \\
\hline $\begin{array}{l}\text { Height for } \\
\text { age } \\
(\mathrm{n}=100)\end{array}$ & $\begin{array}{l}134.21 \pm \\
18.03\end{array}$ & $\begin{array}{l}139.06 \pm \\
17.65\end{array}$ & 30.39 & $<0.05$ & Significant \\
\hline $\begin{array}{l}\text { Weight for } \\
\text { Age } \\
(\mathrm{n}=100)\end{array}$ & $\begin{array}{l}27.98 \pm \\
10.49\end{array}$ & $\begin{array}{l}30.93 \pm \\
10.09\end{array}$ & 11.31 & $<0.05$ & Significant \\
\hline $\begin{array}{l}\text { BMI for } \\
\text { age } \\
(\mathrm{n}=100)\end{array}$ & $\begin{array}{l}14.87 \pm \\
\mathrm{HAZ} \\
(\mathrm{n}=100)\end{array}$ & $\begin{array}{l}14.97 \pm \\
2.02\end{array}$ & 0.81 & $>0.05$ & $\begin{array}{l}\text { Not } \\
\text { significant }\end{array}$ \\
\hline
\end{tabular}

Mean values of height for age and weight for age showed a statistically significant improvement at the end of one year with the given nutritional supplementation $(\mathrm{p}<0.05)$. Though there is an improvement in the mean values BMI at the end of one year, this difference is considered to be not statistically significant $(\mathrm{p}>0.05)$.

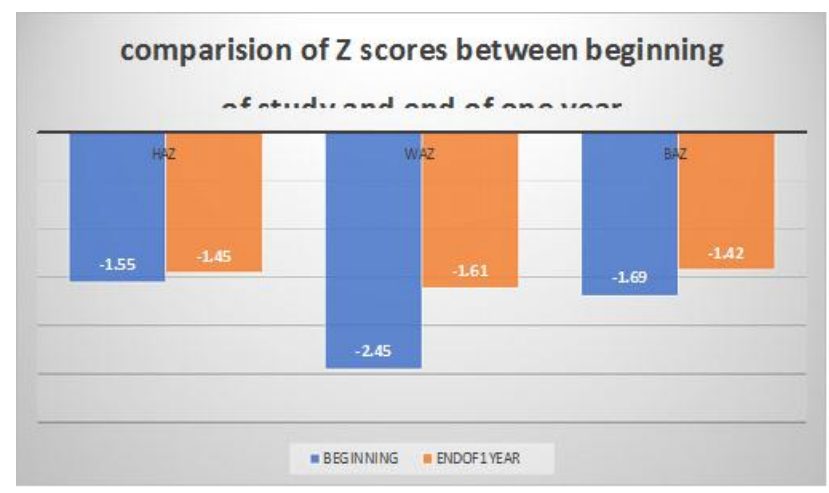

Figure 1: Comparison of $\mathrm{Z}$ score between beginning and at the end of the one year. age and BMI for age showed a statistically significant improvement with the given nutritional supplementation $(\mathrm{p}<0.05)$.

\section{Discussion}

Individuals living with HIV are frequently affected by malnutrition for multiple reasons. Developing countries have a high prevalence of HIV, and the average diet in those communities frequently does not meet the recommended daily requirements of nutrients. ${ }^{[14]}$ Moreover, in severe HIV disease, patients may have increased losses of nutrients because of malabsorption. ${ }^{[15]} \mathrm{HIV}$-infected individuals may also have secondary infections, appetite suppression, and increased energy expenditures, all of which contribute to poor nutritional status. ${ }^{[16]}$ Nutritional status is an important predictor of immunological status for HIV-infected children, with morbidity compounded by the presence of poor nutritional status. ${ }^{[17]}$

In this study, 120 children with proven HIV status were considered, among which 12 children could not meet the inclusion criteria and another 8 children did not give the consent and had to be excluded from the study. The remaining 100 children were provided with the nutrition supplementation and were followed up regularly.

\section{Sex Distribution}

In the present study, forty four percent of the study subjects were boys and the remaining fifty six percent subjects were girls. In a study done by Thakur et $\mathrm{al}^{[18]}$ at Niloufer Hospital, Hyderabad where sixty percent of the study subjects were boys. Rakholia et $\mathrm{al}^{[19]}$ in their study included $62.6 \%$ boys and $37.3 \%$ girls.

\section{Age Distribution}

In the current study, majority of the children were in the age group of 10 to 15 years. The mean age was $11.02 \pm 3.17$ years (median age: 14 years) with the least age being 4 years and and the highest being 18. The mean age of boys was $11.16 \pm 3.15$ years and that of girls was $10.91 \pm 3.20$ years. In the study done by Thakur et $\mathrm{al}^{[18]}$, the median age of the study subjects was 96 months i.e. 8 years (range was 12 months to 204 months) with the majority of the study subjects in the range of 10 to 15 years. In a study done by Rakholia et $\mathrm{al}^{[19]}$, the mean age was $7.15 \pm 3.8$ years.

\section{$\underline{\text { ART Status }}$}

In the present study, $36 \%$ of the children belonged to preART group and $64 \%$ of the children were already on ART at the beginning of the study. Thakur et $\mathrm{al}^{[18]}$ reported that 98 children $(60 \%)$ were on ART and 68 children $(40 \%)$ belonged to the pre-ART group in their study. This distribution is consistent with our study.

The mean $\mathrm{Z}$ score with regard to height for age, weight for 
There are various indicators which can be used to assess the nutritional status in children like anthropometry, biochemical indicators, clinical assessment, etc. Among these, anthropometry is a simple valuable tool and the gold standard for evaluating the nutritional status. Various anthropometric measurements have been recommended and employed for the evaluation of nutritional status of children - weight for age, height for age, weight for height, skin fold thickness, Body Mass Index (BMI), mid-arm circumference, etc. Of these measurements, weight and height (or length) are considered the most reliable, because they provide a direct quantitative assessment of the nutritional status, as determined by growth. ${ }^{[20,21]}$ Furthermore, these two measurements have proved to be reliable as sensitive indices to the improvement of nutritional status in children. ${ }^{[22,23]}$ These indicators provide an indirect measure from which the nutritional status is inferred. In addition, the impact of intervention on nutritional status can be evaluated, permitting a diagnosis of malnutrition in an epidemiological sense. ${ }^{[2]} \mathrm{BMI}$ is a very good index of body's reserve or loss of fat. The extent of wasting, tendency for obesity and obesity can be assessed using reference curves13. Hence, these three parameters i.e. height for age, weight for age and BMI were considered in assessing the nutritional status of children with HIV for the present study.

\section{At The Beginning Of Study Period}

\section{$>$ Height for Age}

In the present study, the mean height was $134.21 \pm 18.03$ $\mathrm{cm}$. At the beginning of study, $59 \%$ of the total study sample were stunted i.e. their height was more than two standard deviations $(<2 \mathrm{SD})$ below their median height for age and gender. Among those $59 \%$ children with stunting, 22\% were boys and $37 \%$ were girls. Out of the $41 \%$ children with normal height for age (i.e. those who fall within the 2 SD of their median), $22 \%$ were boys and $19 \%$ were girls. The mean height for boys was $138.02 \pm 18.52 \mathrm{~cm}$ and the mean height for girls was $131.22 \pm 17.22 \mathrm{~cm}$. In this study the mean height for age $\mathrm{Z}$ scores (HAZ) at the beginning of the study was $-1.55 \pm 1.66$. Though $59 \%$ of the children in this study had stunting, the mean HAZ score does not reflect the same because most of the children who were considered to have a normal height for age had their height above the 50th centile.

In the study by Thakur HS et $\mathrm{al}^{[18]}$, the study subjects were divided into two groups based on their age - less than 5 years and more than 5 years. In those children in the $<5$ year age group, stunting was seen in $65.5 \%$ and the mean HAZ score was $-2.42 \pm 3.1$; and in those who belonged to the $>5$ years age group, stunting was seen in $57.5 \%$ and the mean HAZ score was $-2.25 \pm 1.38$. In our study, only 3 children below the age of 5 years have met the inclusion criteria and hence this kind of grouping was not done in our study. The prevalence of stunting in children in the $>5$ year age group is consistent with the findings in our study.

\section{Weight for Age}

In this study, the mean weight for age was $27.98 \pm 10.49 \mathrm{~kg}$. In boys, the mean was $29.42 \pm 10.3 \mathrm{~kg}$ and in girls it was $26.86 \pm 10.59 \mathrm{~kg}$. Weight for age $\mathrm{z}$ score (WAZ) was calculated for children $<10$ years $(n=34)$. The mean WAZ score for $<10$ years was $-2.45 \pm 0.99$. Among these 34 children in whom the $\mathrm{z}$ score could be calculated, 24 children were underweight i.e. their weight for age was more than 2 SD below the median weight for age. Therefore, among the 34 children in whom the weight for age score could be calculated, $70 \%$ were underweight. In the similar way, Thakur H S et al ${ }^{[18]}$ in their study calculated the WAZ score for children less than 5 years was $-2.18 \pm 2.27$. The mean weight for children $<5$ years was $9.55 \pm \mathrm{kg}$ and that for $>5$ year age group was $22.55 \pm 8.71 \mathrm{~kg}$.

\section{BMI for Age}

The mean BMI in the present study is $14.87 \pm 2.04 \mathrm{~kg} / \mathrm{m} 2$. The mean BMI in boys is $14.86 \pm 1.71 \mathrm{~kg} / \mathrm{m} 2$ and in girls it is $14.87 \pm 2.28 \mathrm{~kg} / \mathrm{m} 2$. At the beginning of the study, 64 children were underweight of which 31 were boys and 33 were girls. The mean BMI for age $\mathrm{z}$ (BAZ) score was -1.69 \pm 0.83.Thakur et $\mathrm{al}^{[18]}$ reported the prevalence of underweight as $24.1 \%$ in children less than 5 years and $45.2 \%$ in those who are more than 5 years. The mean BAZ score in children less than 5 years was $-0.84 \pm 1.77$ and in those who are more than 5 years was $-1.85 \pm$ This finding is consistent with our study.

\section{At The End of One Year \\ $>$ Height for age}

In the present study, the mean height was $139.06 \pm 17.65$ $\mathrm{cm}$. At the end of one year, with the given nutrition supplementation $54 \%$ of the total study sample were stunted i.e. their height was more than two standard deviations $(<2 \mathrm{SD})$ below their median height for age and gender. Among those children with stunting, 20 were boys and 34 were girls. Out of the $46 \%$ children with normal height for age (i.e. those who fall within the 2 SD of their median), 24 were boys and 22 were girls. The mean height for boys was $143.02 \pm 18.19 \mathrm{~cm}$ and the mean height for girls was 135.95 $\pm 16.73 \mathrm{~cm}$. The improvement in height for age with the given nutritional supplementation is considered to be statistically significant $(\mathrm{p}<0.05)$.

In this study the mean height for age $\mathrm{Z}$ scores (HAZ) at the end of one year was $-1.45 \pm 1.15$. There is a statistically significant increase in HAZ score from baseline to 1 year $(Z$ score change, $\mathrm{p}$ value $<0.05)$. This improvement in height for age is similar to the study done by Thakur et al ${ }^{[18]}$ who showed a $0.17 \mathrm{z}$ score change which was considered to be statistically significant $(\mathrm{p}<0.05)$.

\section{Weight for age}


In this study, the mean weight for age was $30.93 \pm 10.09 \mathrm{~kg}$. In boys, the mean was $33.55 \pm 9.7 \mathrm{~kg}$ and in girls it was $28.87 \pm 9.98 \mathrm{~kg}$. The improvement in weight for age with the nutrition supplementation is considered to be statistically significant $(\mathrm{p}<0.05)$. In a study by Amadi $\mathrm{B}$ et $\mathrm{al}^{[25]}$ in Zambia, formula with elemental protein versus standard protocol milk/oil then soy porridge (control intervention) was administered to HIV children and it was found that elemental formula increased WAZ score to 1.2 (0.8 to 1.5) as against (0.4 to 1.2$)$ in the control group. This improvement is statistically significant $(\mathrm{p}<0.05)$.

\section{BMI for age}

In the present study, the mean BMI at the end of one year was $14.97 \pm 2.02 \mathrm{~kg} / \mathrm{m} 2$. The mean BMI in boys was 15.57 $\pm 1.65 \mathrm{~kg} / \mathrm{m} 2$ and that in girls was $14.55 \pm 2.13 \mathrm{~kg} / \mathrm{m} 2$. The improvement in BMI at the end of one year was not statistically significant $(\mathrm{p}=0.42)$. The BAZ score at the end of one year was $-1.41 \pm 1.22$. There is a statistically significant increase in BAZ score from baseline to 1 year ( $0.84 \mathrm{Z}$ score change, $\mathrm{p}$ value $<0.05)$.

In the study by Thakur H S et al ${ }^{[18]}$, the change in BAZ score $0.37 \pm 0.07$ which is considered to be statistically significant $(\mathrm{p}<0.05)$. This is consistent with the findings in our study.

\section{Nutritional Supplementation}

Despite the general understanding that malnutrition and HIV are closely linked, the impact of nutritional supplementation for HIV-infected children has not been clear. Studies on nutritional supplementation in children living with HIV have been few and far.

In the present study, all the 100 children with HIV were given 2 scoops $(60 \mathrm{~g})$ of commercially available protein powder ( total calorie $-210 \mathrm{kcal}$; total protein $-19.2 \mathrm{~g}$ ) and one serving $(30 \mathrm{~g})$ of peanut chikki (total calorie - $150 \mathrm{kcal}$; total protein - $4 \mathrm{~g}$; also contains vitamins and minerals) every day for a period of one year. The children were followed up regularly and at the end of one year a statistically significant improvement in height-for- age, weight-for-age and BMI-for-age was noted.

Though studies on effect of nutrition supplementation on stunting in HIV affected children is lacking, a recent metaanalysis by Bhutta $\mathrm{ZA}$ et $\mathrm{al}^{[26]}$ has concluded that nutritional supplementation (both food and nutrients) in under 5 malnourished children of low socio economic group, reduced HAZ scores by $0.41 \mathrm{Z}$ score.

"A Systematic Review Of Nutritional Supplementation In HIV-Infected Children In Resource-Limited Settings" was conducted by Mc Henry et al ${ }^{[27]}$ (2015) with an objective to compare the general health outcomes among HIV-infected children and youth receiving nutritional supplementation.

\section{Micronutrient Supplementation}

\section{Vitamin A}

An RCT in Uganda by Semba et $\mathrm{al}^{[28]}$, randomized HIV- infected children to receive vitamin A supplementation (200 $000 \mathrm{IU}$, then $60 \mathrm{mg}$ retinal equivalent) every 3 months from age 15 months to 36 months compared to placebo.

\section{$\underline{\text { Zinc }}$}

There were limited studies examining zinc supplementation in HIV-infected children. An RCT that was conducted by Bobat et al29 to determine the safety and efficacy of zinc supplementation (10 mg elemental zinc as sulfate) in HIVinfected children in South Africa ( $\mathrm{n}=96$, aged 6-60 months) showed that after 6 months of supplementation, children gained a median of $7 \%$ of their body weight when compared to only a $2 \%$ gain in children given placebo $(\mathrm{P}=0.02)$.

\section{Multivitamin supplement}

The study by Mda S et al ${ }^{[30]}$ looked at children aged 4 to 24 months $(n=118)$ who were hospitalized for diarrhoea or pneumonia and either given multimicronutrient supplements or placebo during their entire inpatient stay.

\section{Multiple-micronutrient supplementations}

Two publications described findings from a South African RCT of children aged 6 to 24 months, which divided children into the following 3 micronutrient treatment arms: daily vitamin $\mathrm{A}$, daily vitamin $\mathrm{A}$ with zinc, and daily multiple micronutrients that included both vitamin $\mathrm{A}$ and zinc. $^{[31,32]}$

\section{Macronutrient Supplementation}

\section{a. Ready-to-use therapeutic foods (RUTF)}

Prior to coining the term RUTFs, a study in Zimbabwe by Choto R G et al ${ }^{[33]}$ in 1994 looked at the use of Nutrition mix-1 in children $(n=840)$. Of those participants, 460 had HIV-related disease. This dietary supplement, which was a powdered milk protein-based dietary supplement with multiple vitamins and minerals added, was given to children 12 to 36 months of age for a period of 10 months. The average weight gain for children with HIV related disease was found to be $51.2 \%$, which was higher than that of noninfected children $(26.0 \%)$.

\section{b. Whey Protein}

A small, prospective, double-blinded RCT by Moreno YF et $\mathrm{al}^{[34]}$ in 2006 evaluated the outcomes of whey protein concentrate supplements for HIV-infected children $(n=18)$. During the study, $22 \%$ of children in the intervention group and $78 \%$ in the control group presented with coinfections, such as otitis media, pneumonia, and tonsillitis (Fisher exact test $\mathrm{p}=0.0567$ ).

\section{c. $\underline{\text { F75/F100 }}$}

F75 and F100 "starter" formulas are typically used in the acute management of pediatric malnutrition. ${ }^{[35]}$ In Malawi, a prospective cohort study by Fergusson et al ${ }^{[36]}$ examined nutritional recovery using F75 and F100 formulas. 


\section{d. Spirulina}

Spirulina was used as an intervention in a study performed in Burkina Faso by Simpore J et al $(n=170) .{ }^{[38]} \mathrm{HIV}$-infected children receiving spirulina had greater improvement in WHZ than those who did not (22\% versus $10.4 \%)$.

\section{e. Supplementary food rations.}

One clinic-based observational study by Kundu C K et al ${ }^{[39]}$ looked at whether a food supplementation intervention impacted clinic visit adherence among HIV-infected children aged 2 to 12 years $(n=80)$.

Macronutrient supplementation was closely linked to improved anthropometrics for HIV- infected children. In the compiled evidence, RUTF increased average weight gain in HIV - infected children, especially when given with ART. ${ }^{[33,39]}$ F75 and F100 formulas improved mortality rates among malnourished HIV-infected children. ${ }^{[36]}$ Whey protein was associated with a decrease in the reporting of HIV co infections as well as significant decrease in TCD8 counts. ${ }^{[34]}$ Accumulating evidence suggests that a newer supplement, spirulina, can also improve anthropometrics such as WHZ for HIV-infected children. ${ }^{[37]}$ Food itself is the macronutrient that makes a clear difference for both clinicrelated and clinical outcomes; in one study, giving food at clinic visits improved clinic adherence, as well as mean CD4 counts and weight gain, and decreased AIDS-defining illnesses and hospitalizations. ${ }^{[38]}$

\section{Limitations of the Study}

- Children included in this study had access to pediatric HIV healthcare, mostly in urban areas where the standard of care maybe higher than that offered in rural areas, making results difficult to extrapolate to rural areas.

- $\quad$ The children $<2$ years were excluded, because too few respected the inclusion criteria.

- The index study is an observational study and did not have age and sex matched controls, and it is unclear whether the improvement in nutritional status was due to regular visits to the ART centre that may have resulted in better adherence to treatment or an additional benefit of nutritional intervention.

- Restriction of this study to nutritional indices alone rather than including other important indicators such as CD4 count (an indicator of disease progression) is another limitation of this study.

\section{Conclusion}

Very few studies have reported the nutritional practices in HIV-infected malnourished children, this study highlights this gap and the need to focus on these interventions in such children. A better acknowledgement of this problem is needed, that should lead to a better healthcare management of HIV-infected children, with active routine anthropometric measurements easy to perform to allow an earlier detection of malnutrition leading to an appropriate nutritional package. Our study strengthens the World Health Organization recommendation on the need for a nutritional assessment and support that should be an integral part of the care plan of HIV-infected children. Indeed, an early detection of growth impairment could detect, for example, poor treatment response, poor adherence to treatment, and could prevent morbidity and mortality risks. Further studies about associated factors with malnutrition, such as differences in sex need to be examined more closely in prospective designs. Moreover, food supplementation and multivitamin use may improve the nutritional status of the children. Finally, nutritional interventions should be tailored and assessed to improve growth, especially at time of ART initiation that could lead to an optimisation of their clinical response and survival of ART-treated children.

\section{Acknowledgment}

We thankful to management and Department of Paediatrics, Shadan Institute of Medical Sciences for providing all the facilities to carry out this work.

\section{References}

1. Day T, Mideo N, Alizon S.2008. Why is HIV not vector-borne?: Evol Appl,2008 Feb;1(1):17-27.

2. Yogev R, Chadwick E G;Nelson Textbook of Pediatrics 20th ed:chapter 276;1645-1666.

3. 3.ZGAMBO M, HE G, WANG $\mathrm{H}$. Effects of nutritional supplementation on children with HIV/AIDS in China. J Cent South Univ (Med Sci) 2012, 37(3); 305-309.

4. National AIDS Control Organisation, Ministry of Health and Family Welfare Government of India. NACO press release on HIV Estimates 2009. Available at: http://naco.gov.in/NACO/.

5. 5.Uria GA, Midde M, Akam R, Naik PK. Gender differences, routes of transmission, socio demographic characteristics and prevalence of HIV related infections of adults and children in an HIV cohort from a rural district of India. Infect Dis Rep 2012; 4(1):e19.

6. Jones KD, Thitiri J, Ngari M, Berkeley JA. Childhood malnutrition: towards an understanding of infections, inflammation and antimicrobials. Food Nutr Bull 2014; 35(2):6470.

7. Bassichetto KC, Bergamaschi DP, Frainer DES, Garcia VRS, Trovões EAT. Weight and height of people living with HIV/AIDS attended by the Brazilian National Health System Rev Bras Epidemiol 2013; 16(3): 622-32.

8. Ezeonwu BU, Ikefuna AN, Oguonu T, Okafor HU. Prevalence of hematological abnormalities and malnutrition in HIV infected under five children in Enugu. Niger J Clin Pract 2014; 17(3):303-8.

9. Arpadi S. Growth Failure in HIV infected children. J Acquir Immune Defic Syndr 2000; 25 Suppl 1:S37-42.

10. Joint United Nations Program on HIV/AIDS. Status of the global HIV epidemic. Geneva: United Nations; 2008.

11. WHO Anthro software (version 3.2.2.)

12. WHO anthro plus software (v.1.0.4).

13. Elizabeth K E, Nutrition and Child Development, 5th ed. Chapter 4:Triple Burden of Nutrition;183-205.

14. Irlam J HG, Dhansay M. The Effects of Nutritional Interventions in HIV/AIDS:Micronutrients. Pretoria, South Africa: Academy of Science of South Africa (ASSAf); 2007.

15. Bentler M, Stanish M. Nutrition support of the pediatric patient with AIDS. J Am Dietetic Assoc. 1987;87(4):488-491. 
16. Henderson RA, Saavedra JM. Nutritional considerations and management of the child with human immunodeficiency virus infection. Nutrition. 1995;11(2):121- 128.

17. Adetifa I, Okomo U. Iron supplementation for reducing morbidity and mortality in children with HIV. Cochrane Database Syst Rev. 2009;(1):CD006736.

18. Thakur HS,G S Gottapu, Kadali SP, Kulkarni B, Mamidi RS: Effect of nutrition supplementation in children living with HIV at ART centre; Indian J Pediatr (March 2016) 83(3):232-237.

19. Rakholia R, Bano M, Rawat V. Malnutrition among HIV- infected Children by Anthropometric Measures in Poor Outreach Area of a Developing Country and its Relationship with CD4 Counts. . Int J Pediatr 2016; 4(4): 1643-54.

20. KELLER, W.G. and MAEYER, E.M. de. Anthropometry in nutritional surveillance: a review based on results of the WHO collaborative study on nutritional anthropometry, in: Nutrition abstracts and reviews, 46(8): 592-609,1976.

21. SHAN, D.E. and PESTRONK, R.M. Experiences and methodologies in nutrition program evaluation - a literature review. Community Systems Foundation, 184p., Michigan, August, 1979.

22. BEGHIN, 1.D. Applied Nutrition Programs - Research forum, in Proceedings Western Hemisphere, Nutrition Congress IV. Ed. P.L. White and N. Selvey Publishing Sciences Group, Inc. Acton., Massachusetts, 1975.

23. HABITCH, J.P. and BUTZ, W.B. Measurements of health 37 and nutrition effects of large-scale nutrition intervention projects, in: Evaluating the impact of nutrition and health programs, Klein, R.E. and Cols. (eds.), Plenum Press, p. 133-169, New York, 1979.

24. WORLD HEALTH ORGANIZATION - A guideline for the measurement of nutritional impact of supplementary feeding programmes aimed at vulnerable groups. (WHO - FAP/79.1). 85p., Geneva, November, 1979

25. Amadi B, Mwiya M, Chomba E, Thomson M, Chintu C, Kelly P, Walker- Smith J. improved nutritional recovery on an elemental diet in Zambian children with persistent diarrhea and malnutrition. J Trop Pediatr. 2005;51:5-10

26. Bhutta ZA, Ahmed T, Black RE, et al. What works? Interventions for maternal and child undernutrition and survival. Lancet 2008;371:417-40.

27. McHenry SM, Dixit A and Vreeman RC. A Systematic Review of Nutritional Supplementation in HIV-Infected Children in ResourceLimited Settings. Journal of the International Association of Providers of AIDS Care 14(4):313-323.

28. Semba RD, Ndugwa C, Perry RT, et al. Effect of periodic vitamin A supplementation on mortality and morbidity of human immunodeficiency virus- infected children in Uganda: a controlled clinical trial. Nutrition. 2005;21(1):25-31.
29. Bobat R, Coovadia H, Stephen C, et al. Safety and efficacy of zinc supplementation for children with HIV-1 infection in South Africa: a randomised double-blind placebo-controlled trial. Lancet. 2005;366(9500):1862-1867.

30. Mda S, van Raaij JMA, de Villiers FPR, MacIntyre UE, Kok FJ. Short-term micronutrient supplementation reduces the duration of pneumonia and diarrheal episodes in HIV-infected children. J Nutr. 2010;140(5):969-974.

31. Luabeya KK, Mpontshane N, Mackay M, et al. Zinc or multiple micronutrient supplementation to reduce diarrhea and respiratory disease in South African children: a randomized controlled trial. PLoS One. 2007;2(6):e541.

32. Chhagan MK, Van den Broeck J, Luabeya KKA, Mpontshane N, Tucker KL, Bennish ML. Effect of micronutrient supplementation on diarrhoeal disease among stunted children in rural South Africa. Eur J Clin Nutr. 2009;63(7):850- 857.

33. Choto RG. Clinical evaluation of Nutrition Mix-1.A. Dietary supplement in sick and undernourished children. Cent Afr J Med. 1994;40(2):29-32.

34. Moreno YF, Sgarbieri VC, da Silva MN, Toro AADC, Vilela MMd. Features of whey protein concentrate supplementation in children with rapidly progressive HIV infection. J Trop Pediatr. 2006;52(1):34-38.

35. Nutrition MaC. Management of Malnutrition in Children Under Five Years.11 April 2013; http://motherchildnutrition. org/malnutritionmanagement / info / feeding-formulas-f75-f100.html.

36. Fergusson $\mathrm{P}$, Chinkhumba J, Grijalva-Eternod C, Banda T, Mkangama $\mathrm{C}$, Tomkins A. Nutritional recovery in HIVinfected and HIV-uninfected children with severe acute malnutrition. Arch Dis Child. 2009;94(7):512-516.

37. Simpore J, Zongo F, Kabore F, et al. Nutrition rehabilitation of HIVinfected and HIV-negative undernourished children utilizing spirulina. Ann Nutr Metab. 2005;49(6):373-380.

38. Kundu CK, Samanta M, Sarkar M, Bhattacharyya S, Chatterjee S. Food supplementation as an incentive to improve pre-antiretroviral therapy clinic adherence in HIV-positive children-experience from eastern India. J Trop Pediatr. 2012;58(1):31-37.

39. Sunguya BF, Poudel KC, MlundeLB etal. Ready to Use Therapeutic foods (RUTF) improves undernutrition among ART-treated, HIVpositive children in Dar es Salaam, Tanzania. Nutr J. 2012; 11:60.

Copyright: () the author(s), 2020. It is an open-access article distributed under the terms of the Creative Commons Attribution License (CC BY 4.0), which permits authors to retain ownership of the copyright for their content, and allow anyone to download, reuse, reprint, modify, distribute and/or copy the content as long as the original authors and source are cited.

How to cite this article: Rao MN, Ragireddy A. A study on Effect of Nutrition Supplementation in Children Living With HIV at Art CentreA Prospective Observational Study. Asian J. Clin. Pediatr. Neonatol.2020;8(1):74-81.

DOI: dx.doi.org/10.47009/ajcpn.2020.8.1.18

Source of Support: Nil, Conflict of Interest: None declared. 